\title{
EFEKTIVITAS BERBAGAI KONSENTRASI SERBUK KEDELAI (Glycine max (L.) Merill) SEBAGAI BAHAN PENGGANTI PEPTON PADA MEDIA PERTUMBUHAN Candida albicans
}

\author{
Effectiveness of various concentrations of soybean powder (Glycine max (L.) Merill) as
}

Peptone substitute of Candida albicans Growth Medium

\author{
Rahman $^{1}$, Kalma $^{2}$, Widarti ${ }^{3}$, Nihad $^{4}$ \\ 1,2,3 Jurusan Analis Kesehatan Poltekkes Kemenkes Makassar \\ ${ }^{4}$ Prodi Sarjana Terapan TLM Poltekkes Makassar
}

Korespondensi: niinihad@gmail.com/085222220125

\begin{abstract}
Medium is a substance that consists of mixture offood substances (nutrients) that are needed for the growth and breeding of the bodies renic (microorganisms). One of the necessary content of medium for the growth of Candida albicans is the source of nitrogen derived from peptone that contains protein. Peptone usually derived from meat extract (animal). Soybeans have high protein that can be used as a source of peptone substitutes in the growth medium of Candida albicans. The purpose of this research was to determine the effectiveness of various concentrations of soybean powder (Glycine Max (L.) Merill) as peptone substitute of Candida albicans growth medium. The type of this research is a simple experimental by using 2 replications and 5 treatments namely SDA medium as control, soybean powder medium with concentrations of $1 \%, 3 \%, 5 \%$ and $7 \%$. The results of the growth data of Candida albicans were presented in table form and then discussed narratively. The results showed that the average amount of growth of Candida albicans on SDA control medium as much as 92 colonies, in soybean powder medium with a concentration of $1 \%$ average 17 colonies, at a concentration of $3 \%$ average 87 colonies, at a concentration of $5 \%$ average 125 colonies and at a concentration of $7 \%$ average 137 colonies. The conclusion that soybeans can be used as peptone substitute of Candida albicans Growth Medium by showing ineffective results at a concentration of 1\%, .effective at a concentration of $3 \%$ and very effective at concentrations of $5 \%$ and $7 \%$.
\end{abstract}

Keywords : Effectiveness, Soybeans, Peptone, Medium and Candida albicans

\begin{abstract}
ABSTRAK
Media adalah suatu substansi yang terdiri dari campuran zat-zat makanan (nutrisi) yang diperlukan untuk pertumbuhan dan perkembangbiakan jasad renik (mikroorganisme). Salah satu kandungan yang diperlukan media untuk pertumbuhan Candida albicans adalah sumber nitrogen yang berasal dari pepton yang mengandung protein. Pepton biasanya berasal dari ekstrak daging (hewani). Kedelai memiliki kandungan protein yang tinggi yang dapat dijadikan sebagai sumber pengganti pepton yang ada pada media pertumbuhan Candida albicans. Tujuan dari penelitian ini adalah untuk mengetahui efektivitas berbagai konsentrasi serbuk kedelai (Glycine Max (L.) Merill) sebagai bahan pengganti pepton pada media pertumbuhan Candida albicans. Jenis penelitian ini adalah eksperimen sederhana dengan post test with control group. Penelitian ini menggunakan 2 replikasi dan 5 perlakuan yaitu media SDA sebagai kontrol,
\end{abstract}


media serbuk kedelai dengan konsentrasi 1\%, 3\%, 5\% dan 7\%. Hasil data pertumbuhan Candida albicans kemudian disajikan dalam bentuk tabel kemudian dibahas secara narasi. Hasil penelitian menunjukkan bahwa rerata jumlah pertumbuhan Candida albicans pada media kontrol SDA sebanyak 92 koloni, pada media serbuk kedelai dengan konsentrasi $1 \%$ rerata 17 koloni, pada konsentrasi $3 \%$ rerata 87 koloni, pada kosentrasi $5 \%$ rerata 125 koloni dan rerata pada konsentrasi $7 \%$ yaitu 137 koloni. Kesimpulan bahwa kedelai dapat digunakan sebagai bahan pengganti pepton pada media pertumbuhan Candida albicans dengan menunjukkan hasil tidak efektif pada konsentrasi $1 \%$, efektif pada konsentrasi 3\% dan sangat efektif pada konstentrasi 5\% dan 7\%.

\section{Kata kunci : Efektivitas, Kedelai, Pepton, Media dan Candida albicans}

\section{PENDAHULUAN}

Mikroorganisme dapat ditumbuhkan dan dikembangkan pada suatu substrat yang disebut medium. Untuk mengembangbiakkan mikroorganisme seperti jamur, bakteri, ataupun yang lainnya diperlukan media. Media adalah suatu substansi yang terdiri dari campuran zat-zat makanan (nutrisi) yang diperlukan untuk pertumbuhan dan perkembangbiakan jasad renik (mikroorganisme). Komposisi media pertumbuhan dapat dimanipulasi untuk tujuan isolasi dan identifikasi mikroorganisme tertentu sesuai dengan tujuan masing-masing pembuatan suatu media. Mempergunakan bermacam-macam media dapat dilakukan isolasi, perbanyakan, pengujian sifat-sifat fisiologi dan perhitungan jumlah mikroba (Amran, 2016). Seiring dengan perkembangan mikrobiologi di dunia, kebutuhan akan substrat nitrogen sebagai media pertumbuhan mikroorganisme semakin meningkat. Salah satu sumber nitrogen dalam media mikrobiologi yang paling penting adalah pepton. Pepton merupakan salah satu sumber nitrogen bagi pertumbuhan mikroorganisme, yang dapat diekstrak dari bahan-bahan yang mengandung protein. kedelai memiliki kandungan protein yang tinggi. Kandungan nutrisi yang cukup lengkap pada kedelai dapat memenuhi kebutuhan nutrisi yang akan digunakan untuk pertumbuhan jamur. Hasil penelitian yang dilakukan oleh Nuryati (2017), yang mengamati pertumbuhan jamur Aspergillus flavus pada berbagai media tepung kacangkacangan didapat jamur Aspergillus flavus yang tumbuh baik pada media yang berasal dari tepung kedelai dibandingkan dengan media yang berasal dari tepung kacang merah dan kacang hijau. Fachraniah (2002), meneliti pepton dari bungkil kedelai dan khamir dengan enzim papain untuk media pertumbuhan bakteri yang diperoleh hasil pertumbuhan semua bakteri uji pada media pepton yang dihasilkan mirip dengan media pepton komersial.

Tujuan dari penelitian ini yaitu Untuk mengetahui efektivitas berbagai konsentrasi serbuk kedelai (Glycine max (L.) Merill) sebagai bahan pengganti pepton pada media pertumbuhan Candida albicans.

\section{METODE}

\section{Desain, tempat dan waktu}

Jenis penelitian ini dikategorikan sebagai penelitian eksperimen atau percobaan (experimental research). Desain eksperimen yang digunakan dalam penelitian ini adalah desain eksperimen sederhana (Post-test With Control Group). Tempat penelitian dilakukan di Laboratorium Mikrobiologi Jurusan Analis Kesehatan Poltekkes 
Kemenkes Makassar. Waktu penelitian dilaksanakan pada bulan Maret - April 2019.

\section{Bahan dan Alat}

Populasi dalam penelitian ini adalah semua kedelai yang dijual dipasaran Kota Makassar. Sampel dalam penelitian ini adalah kedelai (Glycine $\max ($ L.) Merill) yang dijual di Pasar Pabaeng-Baeng Kota Makassar. Teknik pengambilan sampel dilakukan dengan cara Simple Random Sampling.

Peralatan yang digunakan dalam penelitian ini adalah cawan petri, autoclave, inkubator, oven, hot plate, lamu spiritus, timbangan digital, colony counter, mikropipet, tip, pom karet, pipet ukur, erlenmeyer, gelas ukur, batang pengaduk, sendok tanduk, beaker glass, ose, wadah sampel, object glass, deck glass, mikroskop, alat tulis, laminar air flow, drigalski, blender dan ayakan

Bahan-bahan yang digunakan dalam penelitian ini adalah sampel serbuk kedelai, kultur jamur Candida albicans, agar, dekstrosa, kertas $\mathrm{pH}$, kapas, tisu, aluminium foil, kertas label, kloramfenikol, standar Mc Farland 1, $\mathrm{NaCl}$ steril dan aquadest.

\section{Langkah-Langkah Penelitian}

\section{Pra Analitik}
a. Dilakukan sterilisasi alat
b. Membuat serbuk kedelai

2. Analitik
a. Pembuatan media menggunakan serbuk kedelai sebagai pengganti pepton
b. Inokulasi jamur Candida albicans
c. Pembuatan suspensi Candida albicans 1 unit Mc Farland (Kepadatan jamur 1 x 10 77 $\mathrm{CFU} / \mathrm{ml}$ )
d. Penanaman kepadatan jamur Candida albicans 103 Mc Farland pada media kedelai
e. Pengamatan makroskopik Candida albicans

\section{f. Pengamatan mikroskopik Candida albicans}

3. Pasca Analitik

a. Pelaporan hasil

\section{Pengolahan dan analisis data}

Analisa yang digunakan dalam penelitian ini yaitu secara deskriptif. Data jumlah koloni pada media kontrol dan pada media berbagai konsentrasi serbuk kedelai sebagai bahan pengganti pepton yang disajikan dalam bentuk tabel dan kemudian dibahas secara narasi dengan mendeskripsikan hasil penelitian dengan sampel berbagai konsentrasi kedelai sebagai media pertumbuhan Candida albicans.

\section{HASIL}

Hasil penelitian yang dilakukan pada di Laboratorium Mikrobiologi Jurusan Analis Kesehatan Poltekkes Kemenkes Makassar, menggunakan serbuk kedelai sebagai bahan pengganti pepton pada media pertumbuhan Candida albicans dengan dilakukan sebanyak 2 kali pengulangan pada sampel yang sama, yang telah diinkubasi 48 jam, diperoleh hasil rerata pertumbuhan koloni pada konsentrasi $1 \%$, 3\% 5\% dan 7\% berturut-turut 17 koloni, 87 koloni, 125 koloni dan 137 koloni. Pada media kontrol SDA ditemukan rerata 92 koloni. Hasil konsentrasi media menggunakan serbuk kedelai terbaik didapatkan pada konsentrasi 7\% yaitu 137 koloni.

\section{PEMBAHASAN}

Berdasarkan hasil penelitian yang telah dilakukan menunjukkan bahwa serbuk kedelai dengan konsentrasi $1 \%$ tidak efektif, sedangkan pada konsentrasi 3\% efektif untuk menumbuhkan jamur Candida albicans. Serbuk kedelai sangat efektif dalam pertumbuhan jamur Candida albicans pada konsentrasi 5\% dan 7\%.. Hal ini menunjukkan bahwa kandungan nutrisi 
yang kompleks pada kedelai dimanfaatkan oleh Candida albicans untuk tumbuh dan berkembang. Salah satu kandungan pada kedelai yang dimanfaatkan Candida albicans adalah pepton atau protein yang digunakan sebagai sumber nutrisi pada media pertumbuhan untuk dapat tumbuh dengan baik.

Dari hasil penelitian yang dilakukan pada kelompok kontrol dan masing-masing perlakuan sebanyak 2 kali replikasi pada inkubasi 2 x 24 jam didapatkan hasil populasi koloni Candida albicans yang berbeda-beda. Hal ini menegaskan bahwa kedelai dapat dijadikan sebagai bahan pengganti pepton pada media pertumbuhan Candida albicans. Dari masing-masing perlakuan terdapat perbedaan jumlah populasi koloni Candida albicans. Media serbuk kedelai dengan konsentrasi $7 \%$ memiliki pertumbuhan Candida albicans terbanyak, kemudian disusul dengan konsentrasi 5\%, kontrol (media SDA), konsentrasi 3\%, dan terakhir konsentrasi $1 \%$. Hal ini sangat berkaitan dengan jumlah nutrisi yang terkandung dalam masing-masing perlakuan terutama kadar karbohidrat, karena karbohidrat dan derivatnya merupakan substrat utama untuk metabolisme karbon pada jamur (Gandjar, 2006).

Pada media SDA sumber nutrisi utamanya adalah pepton yang berasal dari ekstrak daging. Sedangkan pada media uji sumber karbohidratnya berasal dari serbuk kedelai. Dalam 100 gram kedelai terkandung protein sebanyak 36 gram (Winarsi, 2010).

Pembuatan rentang konsentrasi serbuk kedelai didasarkan pada penelitian terdahulu, kandungan pepton dan jumlah komposisi pepton dalam media SDA. Konsentrasi media serbuk kedelai 1\% (1 gram / 1 Liter aquadest) didasarkan pada kandungan pepton yang disetarakan dengan kandungan pepton pada media SDA, namun hasil rerata pertumbuhan populasi koloni Candida albicans pada konsentrasi $1 \%$ pada media serbuk kedelai yaitu 17 koloni, lebih sedikit dibandingkan dengan rerata koloni pada media kontrol SDA. Untuk konsentrasi 3\% (3 gram / 1 Liter aquadest) didasarkan pada jumlah komposisi jumlah komposisi pepton yang lebih banyak dibandingkan konsentrasi pepton yang ada pada media SDA. Pada konsentrasi 5\% 5 gram / 1 Liter aquadest) didasarkan pada penelitian-penelitian terdahulu dalam pembuatan media alternatif dengan menggunakan sumber protein yang berbeda. Untuk konsentrasi $7 \%$ konsentrasi ini 7 kali lipat jumlah protein pada media kedelai dibanding media SDA, sehingga hasil pertumbuhan populasi koloni Candida albicans pada konsnetrasi $7 \%$ sangat signifikan lebih banyak dibandingkan populasi koloni pada media SDA yaitu rerata 137 koloni.

Pada pengamatan morfologi, kecepatan pertumbuhan dan jumlah pertumbuhan koloni Candida albicans setelah inkubasi 1 x 24 jam dan $2 \times 24$ jam terdapat perbedaan pada media SDA dan media serbuk kedelai. Pada inkubasi 1 x 24 jam, koloni pada media SDA berbentuk bulat, sedikit cembung, permukaan halus, berwarna putih kekuningan, dengan ukuran diameter 0,1 mm. Sedangkan pada media sebuk kedelai untuk semua perlakuan konsentrasi koloni yang tumbuh sama dengan koloni pada media SDA hanya saja dengan ukuran diameter yang lebih kecil yakni $0,05 \mathrm{~mm}$. Pada pengamatan 2 x 24 jam, pada media SDA, jumlah koloni cenderung tidak mengalami pertambahan, hanya mengalami pertambahan ukuran diameter sebelumnya dari $0,1 \mathrm{~mm}$ menjadi 0,5 $\mathrm{mm}$ dan disertai dengan adanya aroma khas aroma ragi. Sedangkan pada media 
serbuk kedelai jumlah koloni cenderung bertambah dan disertai pertambahan ukuran diameter yang sebelumnya 0,05 $\mathrm{mm}$ menjadi $0,2 \mathrm{~mm}$ dan disertai dengan adanya aroma khas ragi. Setelah inkubasi 2 x 24 jam dilakukan uji mikroskopis pada koloni yang tumbuh pada media SDA dan media serbuk kedelai untuk lebih memastikan koloni yang tumbuh adalah Candida albicans. Setelah dibuat sediaan, sediaan diperiksa dibawah mikroskop dengan perbesaran lensa obyektif 10 kali dan 40 kali, morfologi yang terlihat memiliki bentuk oval atau bulat lonjong. Hasil tersebut yang didapat sesuai dengan teori pada Jawetz (2013) yang menyatakan bahwa spesies Candida albicans tumbuh dengan morfologi oval dan pada media agar yang diinkubasi selama 24 jam pada suhu $37^{\circ} \mathrm{C}$ atau suhu kamar, spesies Candida albicans menghasilkan koloni yang halus, berwarna putih kekuningan (krem) dengan bau khas ragi (Jawetz, 2013).

Berdasarkan jumlah populasi koloni yang tumbuh, media yang efektif adalah media alternatif serbuk kedelai dengan konsentrasi 3\%. Akan tetapi jika berdasarkan kecepatan pertumbuhan dan ukuran koloni, media yang terbaik adalah media SDA. Hal ini sejalan dengan penelitian sebelumnya yang dilakukan oleh Aini (2015) mengenai media alternatif pertumbuhan jamur Candida albicans dengan bahan umbi ganyong, umbi gembili dan umbi garut menghasilkan jumlah koloni yang lebih banyak dibandingkan dengan media PDA akan tetapi memiliki koloni dengan ukuran diameter yang lebih kecil dibandingkan media PDA (Aini, 2015).

Media alternatif dari serbuk kedelai mampu mendukung pertumbuhan jamur. Hal tersebut dikarenakan kedelai memiliki kandungan protein yang tinggi. Hal ini dipertegas oleh Madigan (2002) yang menyatakan bahwa senyawa karbon organik mulai dari gula sederhana, asam organik, polimer rantai pendek dan rantai panjang mengandung karbon hingga senyawa kompleks seperti karbohidrat, protein, lipid, asam nukleat dimanfaatkan jamur untuk membentuk materi sel baru. Candida albicans mengalami pertumbuhan pada media serbuk kedelai pada semua perlakuan. Sehingga dapat dikatakan bahwa serbuk kedelai dapat dipergunakan sebagai media pertumbuhan jamur Candida albicans. Pertumbuhan jamur Candida albicans yang efektif adalah pada konsentrasi serbuk $3 \%$ serta pertumbuhan yang sangat efektif adalah pada konsentrasi $5 \%$ dan $7 \%$.

\section{KESIMPULAN}

1. kedelai dapat digunakan sebagai bahan pengganti pepton pada media pertumbuhan Candida albicans.

2. Rerata jumlah koloni yang tumbuh pada media serbuk kedelai konsentrasi $1 \%, 3 \%, 5 \%$ dan $7 \%$ terhadap pertumbuhan Candida albicans adalah 17 koloni, 87 koloni, 125 koloni, dan 137 koloni dengan menunjukkan hasil tidak efektif pada konsentrasi 1\%, efektif pada konsentrasi $3 \%$ dan sangat efektif pada konsentrasi $5 \%$ dan $7 \%$.

\section{SARAN}

1. Kedelai dapat digunakan sebagai bahan pengganti pepton pada media pertumubuhan Candida albicans.

2. Perlu dilakukan lebih lanjut mengenai media pertumbuhan jamur dengan sumber nutrisi yang sama dan jamur uji yang berbeda

\section{UCAPAN TERIMA KASIH}

Penulis mengucapkan terima kasih pada Poltekkes Kemenkes Makassar Jurusan Analis Kesehatan. 
DAFTAR PUSTAKA

Aini, N. 2015 Media Alternatif Untuk Pertuumbuhan Bakteri Menggunakan Sumber Karbohidrat Yang Berbeda [skripsi]. Surakarta (ID): UMS.

Fachraniah. 2002. Pembuatan Pepton dari Bungkil Kedelai dan Khamir dengan Enzim Papain Untuk Media Pertumbuhan Bakteri. Vol. 13: 260-266

Gandjar, I. Wellyzar, S., Ariyanti, O. 2006. Mikologi Dasar dan Terapan. Jakarta:Yayasan Obor Indonesia.
Jawetz, et. al. 2013. Mikrobiologi Kedokteran. Jakarta: ECG.

Madigan et al. 2002. Biology of Microorganism $8^{\text {th }}$ Edition. New Jersey. Prentice.

Nuryati, A, Huwaina, AD, 2015. Efektifitas Berbagai Konsentrasi Kacang Kedelai (Glycine max (L.) Merill) Sebagai Media Alternatif Terhadap Pertumbuhan Jamur Candida albicans. Vol. 5: 1-4.

Winarsi, H. 2010. Protein Kedelai dan Kecambah Manfaatnya bagi Kesehatan. Yogyakarta: Kanisius 


\section{Tabel 01}

Jumlah koloni per perlakuan

\begin{tabular}{|c|c|c|c|c|c|}
\hline \multirow{2}{*}{ Replikasi } & \multicolumn{5}{|c|}{ Jumlah Koloni / Perlakuan } \\
\hline & Kontrol & $1 \%$ & $3 \%$ & $5 \%$ & $7 \%$ \\
\hline 1 & 89 & 13 & 92 & 133 & 129 \\
\hline 2 & 95 & 21 & 81 & 116 & 145 \\
\hline Jumlah Koloni & 184 & 34 & 173 & 249 & 274 \\
\hline $\begin{array}{c}\text { Rata-rata Jumlah } \\
\text { Koloni }\end{array}$ & 92 & 17 & 97 & 125 & 137 \\
\hline
\end{tabular}

Tabel 02

Kriteria Efektifitas

\begin{tabular}{c|c}
\hline Presentase & Kriteria \\
\hline $100 \%$ & Sangat Efektif \\
\hline $90-100 \%$ & Efektif \\
\hline $80-90 \%$ & Cukup Efektif \\
\hline $60-80 \%$ & Kurang Efektif \\
\hline$<60 \%$ & Tidak Efektif \\
\hline
\end{tabular}

Sumber: Depdagri, Kepmendagri No. 900.327 Th. 1996

Tabel 03

Efektifitas Kedelai terhadap Candida albicans

\begin{tabular}{c|c|c}
\hline $\begin{array}{c}\text { Konsentrasi Kecang } \\
\text { Kedelai }(\%)\end{array}$ & $\begin{array}{c}\text { Persentase } \\
(\%)\end{array}$ & Kriteria \\
\hline 1 & 18,48 & Tidak Efektif \\
\hline 3 & 94,56 & Efektif \\
\hline 5 & 135,86 & Sangat Efektif \\
\hline 7 & 148,91 & Sangat Efektif \\
\hline
\end{tabular}

